\title{
PESAN KELUARGA SAKINAH DALAM TEKS PUISI LISAN PALEBOHU (SUATU PENELITIAN BERDASARKAN KAJIAN HERMENEUTIKA)
}

\author{
Nur Faizah Abdullah ${ }^{1 *}$, Herman Didipu**, Jafar Lantowa***
}

\section{Info Artikel \\ Sejarah Artikel: \\ Diterima Februari 2021 \\ Disetujui Maret 2021 \\ Dipublikasikan Mei 2021}

\begin{abstract}
This study intends to describe the content of peaceful family messages in the oral poemtext of Palebohu. Using a descriptive analysis method, this research obtained the data from the Palebohu text that has been documented in the book, such asthe first edition of Book II concerning Marriage Customary Procedures (by The Indigenous Tribe of Gorontalo) in 2003 compiled by Hi. Medi Botutihe and Farha Daulima, a long with other books that contained Palebohu. The data Were collected from documentation, reading, and recording techniques. Further, the data analysis comprised three steps, i.e., setting the text instructure, analyzing the text, and treating the text in elements. The results revealed seven characteristics as follows: (1) a strong relationship with Allah that can be achieved by worshipping Allah (HablunMinallah) and maintaining relationship with fellow human beings (HablunMinannas). (2) compassion in direct illustration and compassion through deeds. (3) being open, polite, and wiseto each other. (4) communication and concensus. (5) being tolerant and forgiving. (6) fairness and equality that can be achieved by having strong determination. (7) patience and gratitude.
\end{abstract}

Keywords: message, peaceful family, palebohu, hermeneutics.

\section{Alamat Korespondensi:}

Universitas Negeri Gorontalo, Jln Jend. Sudirman No. 6 Kota Gorontalo

Email: nurfaizahabdullah09@gmail.com; herdi.ung.@gmail.com; jafar.lantowa@ung.ac.id 


\section{ABSTRAK}

Penelitian ini bertujuan mendeskripsikan kandungan pesan keluarga sakinah dalam teks puisi lisan palebohu. Metode yang digunakan adalah metode deskriptif analisis. Data dari penelitian ini bersumber dari teks palebohu yang telah didokumentasikan dalam buku, diantaranya: Buku II Tata Cara Adat Perkawinan (Pada Masyarakat Adat Suku Gorontalo), cetakan pertama tahun 2003, yang disusun oleh Hi. Medi Botutihe dan Farha Daulima, dan buku lainnya yang terdapat puisi lisan palebohu. Teknik pengumpulan data yaitu studi dokumentasi, baca dan catat. Teknik analisis data mencakup tiga hal, yaitu: Pertama, mendudukkan teks sebagai sebuah struktur. Kedua, menganalisis teks. Ketiga, memperlakukan teks dalam unsur-unsur. Hasil penelitian menunjukkan terdapat tujuh karakteristik: pertama, kuatnya hubungan dengan Allah, hal ini dapat dicapai dengan dua hal, yaitu; a) beribadah kepada Allah (Hablun minallah) dan b) memelihara hubungan sesama manusia (Hablun minannas). Kedua, kasih sayang, yang dalam palebohu digambarkan dalam dua bentuk, yaitu; a) Kasih sayang dalam gambaran secara langsung, dan b) kasih sayang melalui perbuatan. Ketiga, saling terbuka, santun dan bijak. Dalam palebohu hal ini dapat dicapai dengan; a) sikap saling terbuka, dan b) bersikap santun dan bijak. Keempat, komunikasi dan musyawarah. Kelima, toleran dan pemaaf. Keenam, adil dan persamaan. Sikap adil dan persamaan dalam palebohu dapat dicapai dengan; a) teguh pendirian. Ketujuh, sabar dan syukur, yang oleh peneliti ditemukan dalam palebohu yaitu; a) rasa sabar, dan b) rasa syukur.

Kata kunci: pesan, keluarga sakinah, palebohu, hermeneutika. 


\section{PENDAHULUAN}

Gorontalo merupakan salah satu daerah di nusantara yang terkenal dengan tradisi lisan atau sastra lisan yang dimiliki. Sastra lisan ini disebarkan secara lisan atau dari mulut ke mulut. Hal ini sejalan dengan pendapat Hutomo (1991:1) bahwa yang dinamakan sastra lisan adalah kesusastraan yang mencakup ekspresi kesusastraan warga suatu kebudayaan yang disebarkan dan diturunkan secara lisan (dari mulut ke mulut). Namun pada prinsipnya, ada yang masih bertahan dalam bentuk penyebaran dari mulut ke mulut, ada yang dilantunkan atau disampaikan pada ritual adat tertentu, dan ada pula yang telah didokumentasikan dalam bentuk teks. Sastra lisan Gorontalo cukup beragam. Tuloli (1995:13-14) membagi sastra lisan Gorontalo menjadi 15 ragam, yaitu: me'raji, pi:lu, wungguli, tanggomo, pa:ntungi, lohidu, bunito, bungga, lumadu, leningo, taleningo, malamala, tinilo, tuja'i, dan palebohu. Palebohu merupakan puisi lisan yang berisi nasihatnasihat baik yang diberikan atau disampaikan setelah upacara penobatan, pemberian gelar, serta perkawinan. Sebagian besar sastra lisan tersebut sudah jarang dan hampir tidak ditemukan dalam kehidupan. Salah satu ragam sastra lisan Gorontalo yang sudah jarang ditemukan dalam kehidupan sehari-hari adalah palebohu.

Palebohu adalah salah satu jenis ragam sastra lisan Gorontalo berbentuk puisi, yang berisi pesan dan nasihat. Ada dua upacara adat Gorontalo yang di dalamnya terdapat pembacaan puisi lisan palebohu ini, yaitu: upacara adat penobatan dan upacara adat perkawinan. Pembacaan palebohu biasanya dilakukan oleh seorang Baate atau pemangku adat lainnya. Namun saat ini, di beberapa daerah di Gorontalo hampir tidak ditemukan lagi pembacaan puisi lisan palebohu ini oleh seorang pemangku adat. Melainkan telah diganti oleh kadi maupun tokoh pemuka agama lainnya, serta dibacakan dalam bentuk ceramah yang berisi tentang nasihat perkawinan yang disampaikan berdasarkan pengetahuan dan pengalaman dari orang yang dipercayai untuk menyampaikan palebohu tersebut.

Sastra daerah khususnya sastra lisan terdiri atas ragam jenis. Diantara ragam jenis tersebut ada yang disebut dengan palebohu. Palebohu pada setiap upacara adat tentu 
memiliki perbedaan. Baruadi (2014:35), menyampaikan bahwa palebohu semacam puisi yang berisi pidato atau nasihat. Ragam ini biasanya diucapkan setelah selesai upacara adat. Penceritaannya biasanya terdiri atas tokoh-tokoh adat bekas-bekas pejabat. Kalau diucapkan oleh tokoh adat (Ba;te dan Wuqu), ragam ini diberi nama tahuda. Sebaliknya kalau diucapkan oleh bekas pejabat (Wali Kota dan Bupati) maka ragam ini dinamakan tahuli.

Palebohu adalah jenis puisi bersajak namun tidak terikat oleh banyaknya baris. Palebohu diucapkan atau disampaikan kepada mereka yang akan memasuki era baru, seperti orang yang menikah (nasihat perkawinan), atau di depan raja yang baru dilantik (Idham, 2011:243). Didipu (2013:39), juga berpendapat bahwa palebohu merupakan puisi adat yang dipakai untuk upacara pemberian nasihat setelah upacara perkawinan, penobatan, dan pemberian gelar. Lanjut Didipu, orang yang baru menikah dan baru dinobatkan dianggap sebagai orang yang baru dalam suatu situasi atau kondisi sehingga perlu diberi nasihat.

Selain itu, setiap baris pada teks puisi lisan palebohu ini memiliki makna yang dalam dan berisikan nasihat-nasihat baik untuk diaplikasikan maupun dilaksanakan pada kehidupan sehari-hari. Setiap baris dari teks puisi lisan palebohu ini memiliki makna, arti, serta pesan di dalamnya. Pentingnya puisi lisan palebohu ini untuk tetap dikembangkan juga karena dalam pesan yang terkandung pada setiap baris teks puisi lisan palebohu ini merupakan gambaran dari terciptanya keluarga sakinah yang tentu menjadi harapan setiap pasangan yang tengah atau akan mengarungi bahtera rumah tangga. Keluarga sakinah yang dimaksud adalah bagaimana sebuah keluarga dibangun dengan kedamaian, keamanan, serta kerukunan di dalamnya. Juga keluarga sakinah tentu diwujudkan untuk senantiasa menanamkan serta menumbuhkan cinta kasih dalam keluarga itu sendiri.

Untuk membedah pesan keluarga sakinah yang terkandung dalam teks puisi lisan palebohu ini, digunakan teori hermeneutika. Hermeneutika merupakan studi mengenai pemahaman yang dapat digunakan untuk memahami atau menginterpretasi makna yang terkandung di dalamnya. Grondin (2017:17), menekankan hermeneutika pada interpretasi 
pemahaman yang bukan hanya sebatas pengetahuan. Melalui uraian di atas, bahwa penelitian ini akan membahas mengenai pesan keluarga sakinah yang terkandung dalam teks puisi lisan palebohu yang akan dianalisis menggunakan teori hermeneutika.

\section{METODE}

Pendekatan yang digunakan pada penelitian ini adalah pendekatan kualitatif. Pada penelitian ini, permasalahan atau fenomena yang muncul membutuhkan pemahaman melalui pendekatan kualitatif. Jenis penelitian ini adalah penelitian deskriptif analisis yaitu mendeskripsikan pesan keluarga sakinah yang terkandung dalam puisi lisan palebohu tersebut. Teknik pengumpulan data yang digunakan dalam penelitian ini yaitu: pertama, studi dokumentasi. Kedua, teknik baca, dilakukan untuk mengetahui dan memahami teoriteori yang mendukung penelitian ini. Ketiga, teknik catat. Teknik catat diperlukan untuk mengingat hal-hal yang ditemukan dari teknik studi dokumentasi dan teknik baca.

\section{HASIL DAN PEMBAHASAN}

\section{Hasil}

1. Kuatnya Hubungan dengan Allah

Segala yang terjadi di muka bumi ini tentu telah ada yang mengaturnya. Allah sang maha pencipta, juga yang mengatur segala isi alam semesta termasuk dalam hal membangun rumah tangga. Semuanya tidak akan lepas dari turut kuasa-Nya. Menikah bukan sekadar untuk memenuhi hasrat biologis seseorang, melainkan untuk melangkah pada jenjang kehidupan selanjutnya. Menikah juga merupakan sunnah Rasul sehingga dalam pelaksanaannya baik sebelum maupun setelah pernikahan haruslah bercermin dari cara Rasul. Adapun kuatnya hubungan dengan Allah, dapat dicapai dengan hal-hal berikut.

a. Beribadah kepada Allah (Hablun minallah).

Tahuli li kapala

Batanga tawakala U momaya to Allah

Wolo tato madala
Pesan kepala kampong

Hendaknya kalian tawakal

Dan mengabdi kepada Allah

Dan mengabdi kepada masyarakat 
Mo'opiyo hiyala

Po'o poluwolo palihala

Wawu diila mohutu parkara
Dengan demikian rukunlah rumah tangga

Hendaknya kalian memelihara

Menghindari semua perkara

Data di atas menggambarkan manusia yang memiliki ikatan dengan zat sang Mahakuasa. Pada baris kedua, terdapat kata "batanga" yang secara bahasa memiliki arti raga atau tubuh seseorang. Lebih dari itu, kata "batanga" yang dimaksud dalam palebohu ini adalah tubuh, raga, atau badan, yang di dalamnya terdapat jiwa yang tumbuh sehingga badan tersebut hidup dan mampu menjiwai setiap yang dilakukan. Selanjutnya, kata "tawakala" yang artinya "bertawakal". Ini memberi maksud bahwa manusia harus siap secara lahir dan batin untuk selalu bertawakal dan berserah diri kepada Allah. Kata "momaya" pada baris ketiga kutipan teks palebohu secara bahasa memiliki arti mengabdi. Kata ini akan menjadi luas dan besar maknanya ketika disambungkan dengan kalimat pada baris selanjutnya. Pengabdian kepada Allah dilatih dan ditumbuhkan dalam lingkungan keluarga melalui pembiasaan keluarga untuk melaksanakan ibadah secara bertahap dan bersama, seperti salat berjamaah, tadarus bersama, bersedekah, dan ibadah lainnya. Tujuannya adalah untuk mendekatkan diri kepada Allah. Selain itu, hubungan yang terjalin baik dengan sang pencipta melalui ibadah tentu akan membawa kedamaian dalam keluarga, lingkungan masyarakat, serta dapat membawa rumah tangga menjadi keluarga yang sakinah.

b. Memelihara hubungan sesama manusia (Hablun minannas)
Timongoli mo isingiya
Boli popo amaliya
Kalian harus saling hormat Juga saling beramal

Dila pojina popipiya

Mo hihiyohe (menggoda) lo lo'iya

Wolo ta ngopohiya

Uwito u mo'o hiyariya

Muli hi tihi-tihiya
Janganlah berzina dan berselingkuh

Dengan orang lain Itu yang menyebabkan perceraian Sehingga hidup terpisah-pisah

Data di atas, baris ketiga, terdapat kalimat "dila pojina popipiya" yang artinya "janganlah berzinah dan berselingkuh". Hal ini menekankan bahwa dalam membangun rumah tangga yang baik, haruslah menjaga segala perbuatan buruk seperti zinah dan 
perselingkuhan. Rumah tangga yang bahagia tentu selalu terjaga dari hal tersebut. Perzinahan dan perselingkuhan akan menimbulkan kerusakan tidak hanya kepada pasangan suami istri, melainkan juga bagi keturunannya.

Rumah tangga akan selalu diuji dengan berbagai hal, baik ujian dari dalam rumah tangga maupun ujian yang datang dari luar. Sebagaimana kata "mo hihiyohe" yang terdapat pada baris keempat, yang artinya "menggoda". Godaan yang dimaksud bisa berupa personal yang memasuki wilayah internal rumah tangga, yang dapat memicu kehancuran rumah tangga itu sendiri, juga bisa berupa luapan emosi yang tidak dapat dikendalikan oleh pasangan suami/istri. Akibatnya, rumah tangga akan tergoncang dan jauh dari kedamaian.

Allah mengatur cara bertindak dan bersikap seorang manusia melalui ajaran agama. Sedang oleh para leluhur, untuk mempermudah proses penerapan dan terlaksananya perintah dan anjuran dari Allah, salah satunya dibuat dalam bentuk tradisi yang tetap mengedepankan isi dan pesan mendalam mengenai kehidupan baik untuk setiap manusia

\section{Kasih Sayang}

Kasih sayang dalam sebuah keluarga memiliki peran besar dalam mencapai keluarga sakinah. Dalam hal ini kasih sayang dan cinta yang dibangun atas dasar cinta kepada Allah sehingga menjadikannya abadi serta dijaga dengan keimanan dalam diri setiap anggota keluarga. Saling mengasihi dan menyayangi juga merupakan kewajiban dalam rumah tangga. Bahkan seringkali ini menjadi barometer dari kebahagiaan sebuah keluarga. Kasih sayang dalam sebuah keluarga juga menjadi faktor pendukung dalam bertahannya rumah tangga. Palebohu dalam pengajarannya juga berisi tentang bagaimana rumah tangga dibangun atas dasar saling mengasihi dan menyayangi satu sama lain. Begitu orang-orang terdahulu menuangkannya dalam bentuk puisi lisan palebohu, yang juga menjadi pengingat bagi mempelai pengantin yang akan menjalankan sebuah bahtera rumah tangga, untuk senantiasa menjaga rasa cinta, kasih dan sayang, agar keluarga tersebut bahagia dan langgeng hingga maut memisahkan.

a. Kasih sayang dalam gambaran secara langsung. 
Hihiyala po'o aturuwa

Dila bolo o wuhuwa

Wonu bolo o wuhuwa

Muli lo'u hilipu-lipuwa
Rumah tangga aturlah baik-baik

Janganlah saling mengusik

Kalau sampai terusik

Kamu pasti akan bercerai

Sebuah pernikahan tentu diawali dengan perasaan kasih sayang, baik dari pasangan suami istri itu sendiri, maupun dari pihak keluarga. Diharapkan agar dalam kehidupan setelah pernikahan, suami/istri haruslah saling menjaga satu sama lain. Sejak dulu, hidup saling berkasih sayang memang telah menjadi tabiat bagi para leluhur. Begitu mereka menuangkannya dalam palebohu. Dalamnya pesan yang ingin disampaikan terlihat jelas pada penggunaan kata "moponuwa" yang memiliki arti "dengan air mata". Hal ini memiliki makna mendalam yang bukan sekadar rasa haru, tetapi juga kedalaman rasa serta sepenuh hati dalam pelaksanaannya. Kehidupan berumah tangga tentu jauh berbeda dengan saat sebelum menikah. Akan muncul keegoisan dan ketersinggungan yang bisa dipicu oleh halhal kecil. Setiap pasangan tentu mengharapkan sebuah kedamaian dalam kehidupannya. Tentu dengan tidak saling mengusik dan mengganggu kenyamanan suami/istri, merupakan bentuk kasih sayang yang dapat diberikan.

b. Kasih sayang melalui perbuatan
Timongoli potaabiya
Kamu berkasih-kasihan
Dila posangaja to lahiya
Hindarilah saling menghardik
Hiyalo dila wohi-wohiya
Istri janganlah dicemburui
Ode ta ngopohiya
Kepada orang lain
Uwito u mo'o hiyariya
Itu yang menyebabkan perceraian

Hubungan dalam keluarga yang dibangun dengan niat baik dan sepenuh hati, akan memberi kebahagiaan bagi setiap anggota keluarga yang ada di dalamnya. Begitupun dengan sebuah rumah tangga yang baru akan dibangun. Memelihara kerukunan suami istri dalam rumah tangga merupakan salah satu bentuk kasih sayang dalam sebuah keluarga. Pernikahan tentu diawali dengan perasaan kasih sayang, baik dari pasangan suami istri itu sendiri, maupun dari pihak keluarga. Diharapkan agar dalam kehidupan setelah pernikahan, suami atau istri haruslah saling menjaga. Sebagaimana kata "potaabiya" yang 
dapat diartikan sebagai bentuk saling berkasih-kasihan atau dapat juga diartikan saling merindukan satu sama lain. Orang-orang terdahulu telah sigap dalam hal penggunaan diksi yang tepat untuk memberikan pesan yang dapat melekat bagi pendengarnya. Selain dianjurkan dan diarahkan untuk saling berkasih sayang, ada juga larangan menghardik dalam rumah tangga. Artinya, suami, istri, bahkan anak-anak jangan bersuara keras saat berbicara kepada yang lain. Hardikan biasanya akan membentuk karakter yang keras, kasar, dan jauh dari rasa sayang. Semuanya harus memiliki rasa saling menyayangi, selalu berpikir positif terutama kepada istri. Jangan sampai melemparkan tuduhan-tuduhan yang tidak berdasar kepada pasangan sehingga memicu terjadinya perpecahan dan perceraian.

3. Saling Terbuka, Santun, dan Bijak

Agar lebih saling mengenal kepribadian masing-masing, saling terbuka antara suami dan istri dalam rumah tangga tentu sangatlah dibutuhkan, terlebih mengenai ide, keinginan, pendapat, serta sifat, dan kepribadian diri masing-masing. Selain itu, sikap yang santun dan bijak dari seluruh anggota keluarga dalam kehidupan berinteraksi sesama anggota keluarga akan menciptakan suasana yang nyaman dan tentram. Begitupun dalam palebohu, beberapa hal telah diberi tahu dan diingatkan, seperti berikut:

a. Sikap saling terbuka

Timongoli potoli'anga Kalian hidup rukun dan damai

Dila bolo po totombuwanga Janganlah saling mengusut Dila pomite-mite batanga Wonu ma mowali bijana Jangan mengusut asal usul Mo'o hina sama-sama

Kalau sudah menjadi fitnah

Kamu akan hina bersama-sama

Hidup rukun dalam rumah tangga bisa dijalankan apabila ada keterbukaan dalam keluarga. Dengan begitu, suami atau istri akan lebih tenang dan tidak akan berperasangka buruk pada pasangannya. Kehidupan yang saling terbuka antara suami dan istri bukanlah hal yang perlu dihindari. Melainkan dapat lebih memudahkan suami dan istri saling memahami satu sama lain. Kerukunan yang terjalin melalui hal inilah yang akan membuat suami atau istri tidak akan saling mengusut satu sama lain. Hal ini menjadi pengajaran yang telah sejak dulu dilakukan para leluhur. Pada kalimat "dila bolo po totombuwanga" yang 
artinya "janganlah mengungkit” atau jangan saling mengungkit”, yang jelas akan membawa pertengkaran dalam rumah tangga. Mengungkit dalam artian membahas kembali masa lalu dari suami atau istri, hingga membuatnya marah atau tersinggung. Sebelum menikah, tentu perlu adanya pengenalan antara suami dan istri. Begitupun setelah menikah, apa yang belum diketahui pasangan, perlu untuk diberi tahu. Ini akan menjadi salah satu pembangun keharmonisan dalam keluarga dan juga menghindari terjadinya pengaruh serta fikiran buruk dari orang lain mengenai pasangan.

b. Bersikap santun dan bijak

Wawu timongoli lo nika lo nyawa Hiyala po'o dahawa Wawu dila bolo pomilaya

Daata ta arinaya Mohinggi tinelo cahaya
Kamu kawin dengan sepenuh hati Peliharalah kerukunan suami istri Janganlah sombong Banyak yang mendengki Ingin memudarkan nama baik

Sejak dulu, para leluhur telah mewanti-wanti untuk setiap pasangan yang telah maupun baru akan melaksanakan pernikahan, untuk menjaga serta merawat rumah tangganya melalui pesan dalam palebohu. Terlihat bagaimana dipesankan untuk menjaga rumah tangga lebih dulu melalui suami atau istri. Biasanya, karena merasa telah saling memiliki satu sama lain, suami atau istri lengah dari tugas dan tanggung jawabnya untuk memberi perhatian kepada pasangan. Akibatnya, suami atau istri menjadi disia-siakan. Seperti kata "pomilaya" yang secara bahasa memiliki arti "sia-sia". Kaitan antara kata "pomilaya" yang digunakan untuk menggambarkan kata sombong adalah ketika istri atau suami yang terlalu fokus pada diri sendiri, hingga tidak lagi memperhatikan pasangan, maka akan memberikan dampak buruk dalam rumah tangga. Sikap sombong yang dimiliki setiap manusia tentu hanya akan membawanya dalam keburukan. Sehingga, setiap pasangan suami, istri, maupun anggota keluarga lainnya diharapkan selalu bersikap santun, baik terhadap sesama anggota keluarga, maupun orang lain. Sikap yang santun dari setiap anggota keluarga juga dapat memberikan suasana nyaman dan tentram dalam keluarga.

4. Komunikasi dan Musyawarah 
Komunikasi yang terjalin baik serta selalu bermusyawarah dalam hal pengambilan keputusan dalam sebuah rumah tangga tentu akan menghasilkan keluarga yang saling memahami satu sama lain.

\section{Wau timongoli poduutola Dila bolo polo'iya hilotoola Uwito mowali li'ola Uwito mo'o buubutola Tunggulo hiyalo molola}

\author{
Kamu hidup seia sekata \\ Jangan berbicara dengan suara keras \\ Itu yang menyebabkan silang sengketa \\ Itu yang menyebabkan pertengkaran \\ Sehingga terjadi perceraian
}

Kerukunan dalam rumah tangga tentu menjadi tanggung jawab setiap anggota keluarga. Apabila terjadi masalah dalam sebuah keluarga, suami atau istri haruslah saling menjaga komunikasi agar senantiasa dapat saling memahami satu sama lain juga tidak memperkeruh suasana. Begitupun dalam hal berkomunikasi. Komunikasi yang baik dalam keluarga tentu sangat diharapkan, juga dapat menghasilkan keluarga yang saling memahami satu sama lain. Dengan begitu, suami atau istri akan selalu lembut dalam bertutur juga tidak saling bicara dengan suara keras. Orang-orang terdahulu telah memberikan contoh bahwa cara menjaga komunikasi hingga penyelesaian masalah yang dilakukan melalui musyawarah itu sangat membantu. Begitupun dalam rumah tangga. Setiap hal yang selalu disepakati bersama oleh suami dan istri dalam keluarga tentu menggambarkan bagaimana sebuah komunikasi baik selalu terjalin dalam rumah tangga tersebut.

\section{Toleran dan Pemaaf}

Setiap rumah tengga tentu memiliki konflik dan masalahnya masing-masing. Masalah tersebut bisa terjadi antar anggota keluarga dengan orang lain, dan mungkin pula terjadi antar anggota keluarga itu sendiri. Ada banyak pemicu masalah dalam keluarga, satu diantaranya adalah masalah-masalah kecil yang disebabkan oleh perbedaan pendapat. Sehingga, saling toleran dalam keluarga sangatlah dibutuhkan. Selain itu, yang tak kalah penting adalah saling memaafkan satu sama lain. Meminta maaf mungkin bukanlah hal besar namun kadang kala berat untuk dilakukan. Nasihat untuk saling toleran dan memaafkan telah diajarkan oleh para leluhur sejak dulu. Sebagaimana yang dituangkan dalam palebohu, seperti berikut. 
Palebohu wawu pongajari

Wonu woluwo u banari

Tuwango ma'o to akali

Wonu woluwo u mo'opali

Kiki boli sabali
Nasehat dan pengajaran

Kalau ada yang benar

Camkanlah baik-baik

Kalau ada yang menyakitkan hati

Tahan dan sabarkan

Dalam kehidupan rumah tangga, sering kali menahan diri dan bersabar belum menjadi kebiasaan yang melekat, sehingga kesalahan-kesalahan kecil dari pasangan suami/isteri kadangkala menjadi awal konflik yang berlarut-larut. Tentu saja memaafkan bukan berarti membiarkan kesalahan terus terjadi, tetapi memaafkan berarti berusaha untuk memberikan perbaikan dan peningkatan. Pesan tentang sikap toleran dan saling memaafkan juga telah Allah tekankan pada beberapa surat dalam Alquran, yang artinya "(yaitu) orang-orang yang menafkahkan (hartanya) baik di waktu lapang maupun sempit, dan orang-orang yang menahan amarahnya dan memaafkan (kesalahan) orang. Allah menyukai orang-orang yang berbuat kebajikan” (Ali 'Imran:134).

\section{Adil dan Persamaan}

Berlaku adil tentu sangat dianjurkan, baik perlakuan adil dari suami ke istri, maupun dari istri ke suami. Selain itu, berlaku adil juga wajib dilakukan kepada anak tanpa membeda-bedakan satu dengan yang lain. Untuk mencapai keluarga sakinah, sikap adil dan persamaan haruslah diterapkan dalam keluarga, dengan cara berikut.

a. Teguh pendirian

Po'o toheta pahamu Mona'o delo posalamu

Pohintu to nikamu

Alihu dila mo'otoduwo u haramu
Peganglah kuat pendirian

Kalau pergi sebaiknya member salam

Minta izin pada istrimu/suamimu

Agar tidak membuat yang haram

Pesan tentang keluarga sakinah yang tertuang melalui palebohu tentu banyak yang telah jelas dituliskan dan ditegaskan. Tujuannya agar mempelai berdua serta yang mendengarkan senantiasa dapat mengutip dan mengaplikasikannya dalam kehidupan sehari-hari. Seperti kutipan pada baris pertama palebohu berbunyi "po'o toheta pahamu” yang artinya "peganglah teguh pendirian". Maknanya, setiap yang akan maupun telah 
mengemban tanggung jawab dalam membangun rumah tangga haruslah memiliki pegangan, serta berpegang teguh pada pendiriannya. Tercapainya sebuah keluarga yang aman, damai, dan bahagia, tentu tidak lepas dari faktor pendukung, baik itu dari luar maupun dalam rumah tangga itu sendiri. Hal ini telah menjadi perhatian khusus dari para pendahulu. Bagaimana mereka memberikan contoh dan pengajaran dalam hal membangun rumah tangga. dengan pegangan yang kuat dan kokoh, rumah tangga tidak akan mudah goyah dengan ujian dan cobaan kecil yang Tuhan berikan.

7. Sabar dan Syukur

Sabar dan syukur adalah kunci dari sebuah kehidupan. Sabar dalam artian mampu bertahan dalam keadaan apapun. Begitupun dengan syukur. Syukur dalam artian selalu berserah kepada Allah atas berkah maupun ujian dalam rumah tangga yang Allah limpahkan kepada setiap pasangan suami dan istri. Untuk mencapai rumah tangga yang sakinah, rasa sabar dan syukur harus ditanamkan dalam diri setiap anggota keluarga. Berikut peneliti uraikan berdasarkan data yang ditemukan dalam teks palebohu.

a. Rasa sabar

$\begin{array}{ll}\text { Palebohu wawu pongajari } & \text { Nasehat dan pengajaran } \\ \text { Wonu woluwo u banari } & \text { Kalau ada yang benar } \\ \text { Tuwango ma'o to akali } & \text { Camkanlah baik-baik } \\ \text { Wonu woluwo u mo'opali } & \text { Kalau ada yang menyakitkan hati } \\ \text { Kiki boli sabali } & \text { Tahan dan sabarkan }\end{array}$

Setiap manusia memiliki hak dan kewajiaban untuk memperbaiki diri dengan rasa sabar. Kesabaran yang dimaksud adalah mampu menahan diri dari segala sesuatu yang dapat menyakitkan hati. Hal ini terdapat dalam kutipan palebohu di atas, pada baris kelima yaitu "kiki boli sabali" artinya "tahan dan sabarkan". Orang-orang terdahulu telah mengajarkan kita mengenai kesabaran. Selain itu, pengajaran atau pesan mengenai kesabaran tidak hanya sekadar pesan dari para leluhur, tetapi juga menjadi perintah dari Allah SWT., sebagaimana yang terdapat dalam Alquran yang artinya: "Sesungguhnya Allah beserta orang-orang yang bersabar" (Q.S Al-Baqarah:153). Sehingga penting bagi setiap orang memiliki rasa sabar. 
Dalam sebuah pernikahan, rumah tangga haruslah dibangun dengan sepenuh hati. Begitupun dalam sebuah keluarga, apa dan siapa pun bisa menjadi pemicu suatu masalah dan kemarahan muncul. Baik itu suami, istri, maupun anak, sehingga perlu adanya pondasi kesabaran dalam keluarga itu sendiri.

b. Rasa syukur

Tahuli li Maama Dila poloyarilo batanga Heemaati to tuwanga Alihu mo 'otapu mo'o hama
Pesan ibunda berdua

\section{Jangan beroyal diri}

Hendaknya hidup hemat

Agar selalu berkecukupan

Syukur dapat dimaknai dalam beberapa hal. Ada yang bersyukur atas penerimaan, ada pula syukur atas kehilangan. Syukur artinya rasa terima kasih kepada Allah Swt. Sehingga tidak harus menunggu nikmat kebahagiaan untuk bersyukur, melainkan juga ada ujian atau cobaan dari Allah yang tetap harus disyukuri. Bentuk rasa syukur yang dimaksud oleh kutipan palebohu di atas, yaitu pada baris kedua "dila poloyarilo batanga" yang artinya "jangan beroyal diri", yakni rasa syukur atas nikmat yang Allah berikan dengan memanfaatkan sesuatu sesuai dengan porsinya. Sesuatu yang berlebih-lebihan tentu tidak disukai Allah, terlebih dalam hal kebutuhan rumah tangga. Berlebih-lebihan juga merupakan bentuk ketidaksyukuran atas nikmat yang telah Allah berikan. Rasa syukur atas nikmat yang Allah berikan bisa ditunjukan dengan kehati-hatian dalam menggunakan uang dan membelanjakannya untuk keperluan rumah tangga. Kehidupan tidaklah hanya pada saat itu saja, melainkan juga akan datang. Perlu untuk berhemat dan tidak boros, agar keperluan mendatang juga keperluan mendadak dapat dipenuhi.

\section{Pembahasan}

Konsep keluarga sakinah menurut Chadijah dapat dicapai dengan tujuh faktor yang menjadi karaktersistik keluarga sakinah, yaitu: 1) kuatnya hubungan dengan Allah, 2) Kasih sayang, 3) Saling terbuka, santun, dan bijak, 4) Komunikasi dan musyawarah, 5) Toleran dan pemaaf, 6) Adil dan persamaan, 7) Sabar dan syukur. Berdasarkan hasil analisis yang peneliti lakukan, peneliti menemukan ke tujuh karakteristik tersebut dalam 
teks puisi lisan palebohu. Hanya saja, peneliti menemukan bentuk karakteristik yang lebih bersifat khusus. Seperti berikut ini.

Dalam pandangannya, Chadijah berpendapat bahwa setiap manusia memiliki kewajiban untuk selalu mendekatkan diri kepada Allah. Dalam setiap aktivitas, haruslah ada bagian keterlibatan Allah di dalamnya. Menikah adalah salah satu bentuk dan cara untuk menambah keimanan dan kedekatan manusia dengan penciptanya. Oleh karena menikah merupakan salah satu tanda kebesaran Allah Swt, sebagaimana diungkap dalam Alquran (Q.S Al-Rûm:21), maka ia bernilai sakral dan signifikan. Selain itu, menikah juga merupakan perintah-Nya, seperti yang dijelaskan dalam Alquran (Q.S An-Nur:32), yang berarti bahwa suatu aktifitas yang bernilai ibadah dan merupakan Sunnah Rasul dalam kehidupan. Sebagaimana ditegaskan pula dalam salah satu hadits,"Barangsiapa yang dimudahkan baginya untuk menikah, lalu ia tidak menikah maka tidaklah ia termasuk golonganku" (HR. Al-Thabrani dan Al-Baihaqi).

Berdasarkan hasil analisis data yang peneliti lakukan, peneliti menemukan hal seperti yang dijelaskan dan dimaksudkan oleh Chadija. Dalam teks puisi lisan palebohu, terdapat pesan tentang pentingnya seorang hamba untuk mendekatkan diri kepada Allah dan menjaga kuatnya hubungan dengan Allah. Namun oleh peneliti, kuatnya hubungan dengan Allah dibagi menjadi dua hal yaitu: 1) beribadah kepada Allah (Hablun minallah) dan 2) memelihara hubungan sesama mausia (Hablun minannas). Hal ini sesuai dengan yang peneliti temukan dalam hasil analisis teks puisi lisan palebohu bahwa untuk mencapai puncak kuatnya hubungan dengan Allah, palebohu disajikan dalam bentuk perintah dan cara beribadah kepada Allah guna mendekatkan diri kepada-Nya. Selain itu, menjaga dan memelihara hubungan dengan sesama manusia juga akan membawa manusia tersebut kepada pintu kedekatan dengan sang pencipta.

Begitu pula yang terdapat dalam teks puisi lisan palebohu, bahwa mengenai kasih sayang yang menjadi pendapat Chadija juga terdapat di dalamnya. Dalam palebohu, berdasarkan hasil analisis, peneliti menemukan dua bentuk pesan tentang kasih sayang untuk mewujudkan sebuah keluarga sakinah. Pertama, kasih sayang dalam gambaran secara 
langsung, yaitu bagaimana palebohu memberi pengajaran mulai dari sebuah pernikahan yang dilakukan dengan sepenuh hati, mengenai rasa saling sayang dan cinta antar masingmasing anggota keluarga, juga cara menjaga rasa kasih sayang dalam rumah tangga. Kedua, kasih sayang melalui perbuatan. Bahwa dalam membangun sebuah rumah tangga yang sakinah, kasih sayang tidak hanya dapat berupa kata-kata semata melainkan dengan bentuk perwujudan sikap dan pelaksanaannya. Bagaimana cara memperlakukan suami/istri, anak, orang tua, mertua, dan anggota keluarga lainnya, dapat menjadi salah satu ukuran menjaga rasa cinta dan kasih sayang dalam keluarga.

Merawat cinta kasih dalam keluarga ibaratnya seperti merawat tanaman, maka pernikahan dan cinta kasih harus juga dirawat agar tumbuh subur dan indah, di antaranya dengan mu'âsyarah bi al-ma'rûf, yakni memperbaiki ucapan, perbuatan, dan penampilan. Rasulullah saw mengungkapkan bahwa "Sebaik-baik orang di antara kamu adalah orang yang paling baik terhadap isterinya; dan aku (Rasulullah) adalah orang yang paling baik terhadap isteriku". (HR.Thabrani \& Tirmidzi).

Pada prinsipnya, untuk mencapai keluarga sakinah, perlu adanya sikap saling terbuka, santun, dan bijak pada masing-masing anggota keluarga. Sebagaimana pendapat yang dikemukakan oleh Chadija bahwa secara fisik, suami dan istri telah dihalalkan oleh Allah Swt untuk saling terbuka saat jimak, padahal sebelum menikah hal itu adalah sesuatu yang diharamkan. Maka hakikatnya, keterbukaan itu pun harus diwujudkan dalam interaksi kejiwaan (syu"ur), pemikiran (fikrah), sikap (mauqif), dan tingkah laku (akhlâq), sehingga masing-masing dapat secara utuh mengenal hakikat kepribadian suami atau isterinya dan dapat memupuk sikap saling percaya (tsiqoh) satu sama lain. Hal tersebut dapat dicapai apabila suami dan istri saling terbuka dalam segala hal menyangkut perasaan dan keinginan, ide dan pendapat, serta sifat dan kepribadian.

Selain itu, sikap yang santun dan bijak dari seluruh anggota keluarga dalam interaksi kehidupan berumah tangga akan menciptakan suasana yang nyaman dan indah. Suasana yang demikian sangat penting untuk perkembangan kejiwaan (maknawiyah) anakanak dan pengondisian suasana untuk betah tinggal di rumah. Ungkapan yang menyatakan 
"Baiti Jannati" (Rumahku Syurgaku) bukan semata dapat diwujudkan dengan lengkapnya fasilitas dan luasnya rumah tinggal, akan tetapi lebih disebabkan oleh suasana interaktif antara suami dan istri dan orang tua dan anak yang penuh santun dan bijaksana, sehingga tercipta kondisi yang penuh keakraban, kedamaian, dan cinta kasih (Chadijah, 2018:120).

Berdasarkan hasil analisis yang peneliti lakukan, peneliti menemukan hal serupa dalam teks puisi lisan palabohu. Palebohu memberikan pesan dan pengajaran mengenai sikap saling terbuka, santun, dan bijak. Namun dalam hal ini, oleh peneliti, dipisah manjadi dua hal yang berbeda, yaitu: 1) Bersikap saling terbuka dan 2) Bersikap santun dan bijak.

Sikap saling terbuka dalam sebuah rumah tangga sangatlah dibutuhkan. Dengan sikap saling terbuka, maka setiap anggota keluarga akan saling dekat dan kenal satu smaa lain. Namun jika sebaliknya, maka akan menimbulkan perselisihan di dalamnya. Sebagaimana hadis Rasulullah SAW., "jiwa berkelompok-kelpompok bagaikan kelompok tentara. Jiwa yang saling mengenal akan harmonis dan yang tidak saling mengenal akan berselisih". Maksudnya bahwa sikap saling terbukalah yang akan membuka jalan keharmonisan tanpa keraguan dalam sebuah keluarga. Selanjutnya bersikap santun dan bijak juga menjadi salah satu perhatian khusus dalam palebohu. Sebagaimana hasil analisis yang peneliti lakukan, bahwa sikap santun dan bijak juga menjadi salah satu penyokong terwujudnya keluarga sakinah.

Berdasarkan analisis yang peneliti lakukan, peneliti menemukan hal ini di dalam palebohu. Ini membuktikan bahwa dalam kedudukannya, sangat penting untuk menjaga komunikasi dalam rumah tangga, guna menjaga keharmonisan dalam sebuah keluarga. Untuk mencapai keluarga sakinah, seorang ayah adalah ia yang mempu mewujudkan suasana keluarga yang harmonis dan komunikatif, sehingga tercipta komunikasi yang dialogis antara orang tua dan anak. Terutama peran seorang ayah (suami). Menurut Basri (1995:80), komunikasi dalam keluarga memiliki beberapa fungsi, yakni pertama, sarana untuk mengungkapkan kasih sayang; kedua, media untuk menyatakan penerimaan atau penolakan atas pendapat yang disampaikan; ketiga, sarana untuk menambah keakraban hubungan sesama anggota keluarga; dan keempat, menjadi barometer bagi baik atau 
buruknya kegiatan komunikasi dalam sebuah keluarga.

Selain itu, dalam menyelesaikan sebuah masalah dalam keluarga juga perlu adanya komunikasi baik yang terjalin. Hal ini dapat diwujudkan dalam bentuk musyawarah guna mencapai kesepakatan bersama. Salah satu bentuk tercapainya suatu musyawarah dalam keluarga adalah dengan menerapkan pola hubungan demokratis dalam keluarga. Seperti yang telah diisyaratkan dalam Alquran (Q.S Al-Baqarah:233) tentang bagaimana seharusnya hubungan suami istri pada saat mengambil keputusan berkaitan dengan masalah keluarga dan anak-anak dan (Q.S Ali Imran:159) tentang sikap-sikap yang harus diterapkan dalam musyawarah.

Dua insan yang berbeda latar belakang sosial, budaya, pendidikan, dan pengalaman hidup bersatu dalam pernikahan, tentunya akan menimbulkan terjadinya perbedaanperbedaan dalam cara berfikir, memandang suatu permasalahan, cara bersikap atau bertindak, juga selera (makanan, pakaian, dsb). Potensi perbedaan tersebut apabila tidak disikapi dengan sikap toleran (tasamuh), dapat menjadi sumber konflik atau perdebatan. Oleh karena itu, masing-masing suami atau istri harus mengenali dan menyadari kelemahan dan kelebihan pasangannya, kemudian berusaha untuk memperbaiki kelemahan yang ada dan memupuk kelebihannya (Chadijah, 2018:122).

Sikap toleran dan pemaaf ini juga peneliti temukan di dalam palebohu. Ini menggambarkan bahwa untuk mencapai keluarga yang sakinah, penting bagi sebuah keluarga untuk selalu bersikap toleran dan pemaaf. Sikap toleran menuntut adanya rasa saling memaafkan, sehingga keduanya tidak dapat saling dipisahkan. Maka demikian bahwa pendapat Chadijah mengenai karakteristik keluarga sakinah tentang toleransi dan pemaaf juga terdapat dalam teks puisi lisan palebohu, guna memberi pesan dan pengajaran bagi pasangan yang sedang atau akan menjalankan kehidupan berumah tangga.

Chadijah (2018:124) berpendapat bahwa sikap adil merupakan faktor yang harus muncul dalam keluarga sakinah. Adil berarti seimbang dan proporsional. Dengan demikian, keadilan dapat diartikan sebagai keseimbangan, tidak berat sebelah, tidak pilih kasih, tidak diskriminatif, dan memenuhi aspek pemenuhan kebutuhan berdasarkan proporsi dan 
kebutuhan masing-masing.

Dalam proses analisis, peneliti menemukan data yang relevan dengan hal yang disebutkan oleh Chadijah tersebut dalam teks puisi lisan palebohu. Namun tidak secara langsung disampaikan bentuk adli di dalam palebohu tersebut, melainkan secara gambarannya. Sehingga peneliti menyebutnya dengan bagian teguh pendirian. Seseorang yang teguh pendiriannya tentu dengan sadar akan memilih dan memilah, serta memahami tentang adil dan persamaan. Pentingnya berlaku adil dan persamaan dalam sebuah keluarga, karena jika satu diantaranya tidak teguh pendiriannya maka akan muncul rasa iri, dengki, hingga muncul niat buruk ketika merasa didiskriminasi. Adil juga dapat dicegah dengan rasa saling peduli satu sama lain, tanpa mendiskriminasi bagiannya. Seperti yang digambarkan dalam Alquran tentang bahaya yang akan ditimbulkan oleh perasaan didiskriminasikan antar saudara, yaitu terdapat dalam (Q.S Yusuf: 8). Sehingga kisah ini menjadi salah satu bukti tentang pentingnya prinsip dan pemenuhan rasa keadilan dalam keluarga. Selain itu, dalam palebohu terdapat gambaran tentang keadilan yang tidak secara langsung disebutkan bentuknya. Misal dalam pelaksanaannya, palebohu tidak dibuat khusus untuk salah satu pihak, melainkan untuk keduanya (suami atau istri), sehingga palebohu juga disebut mengajarkan sikap adil. Begitu pula dengan rasa syukur yang merupakan bagian yang tak dapat dipisahkan dalam kehidupan berumah tangga.

\section{SIMPULAN}

Berdasarkan hasil penelitian, dapat disimpulkan bahwa pesan keluarga sakinah terdapat dalam teks puisi lisan palebohu. Sebagaimana yang telah diuraikan peneliti, yaitu: a) beribadah kepada Allah (Hablun minallah) dan b) memelihara hubungan sesama mausia (Hablun minannas). Kedua, kasih sayang, yang dalam palebohu digambarkan dalam dua bentuk, yaitu: a) Kasih sayang dalam gambaran secara langsung, dan b) kasih sayang melalui perbuatan. Ketiga, saling terbuka, santun dan bijak. Dalam palebohu hal ini dapat dicapai dengan: a) sikap saling terbuka, dan b) bersikap santun dan bijak. Keempat, komunikasi dan musyawarah. Kelima, toleran dan pemaaf. Keenam, adil dan persamaan. 
Sikap adil dan persamaan dalam palebohu dapat dicapai dengan: a) teguh pendirian.

Ketujuh, sabar dan syukur, yang oleh peneliti ditemukan dalam palebohu yaitu: a) rasa sabar, dan b) rasa syukur.

\section{DAFTAR RUJUKAN}

Baruadi, Moh. Karmin. 2014. Sastra Lisan Gorontalo Bagian Dari Tradisi Lisan Universal. Jurnal Bahasa, Sastra dan Pembelajaran. Vol. 4 No. 1.

Basri, Hasan. 1995. Keluarga Sakinah: Tinjauan Psikologi dan Agama. Yogyakarta: Pustaka Pelajar

Chadijah, Siti. 2018. Karakteristik Keluarga Sakinah dalam Islam. Jurnal Rausyan Fikr. Vol. 14, No. 1.

Didipu, Herman. 2013. Sastra Daerah (Konsep Dasar dan Ancangan Penelitiannya). Yogyakarta: Deepublish.

Grondin, Jean. 2017. Sejarah Hermeneutik (Dari Plato Sampai Gademer). Jogjakarta: ArRuzz Media.

Hutomo, S.S. 1991. Mutiara yang Terlupakan: Pengantar Studi Sastra Lisan. Surabaya: HISKI Komisariat Jawa Timur.

Tuloli, Nani. 1995. Khazanah Sastra Lisan. Gorontalo: STKIP Gorontalo. 